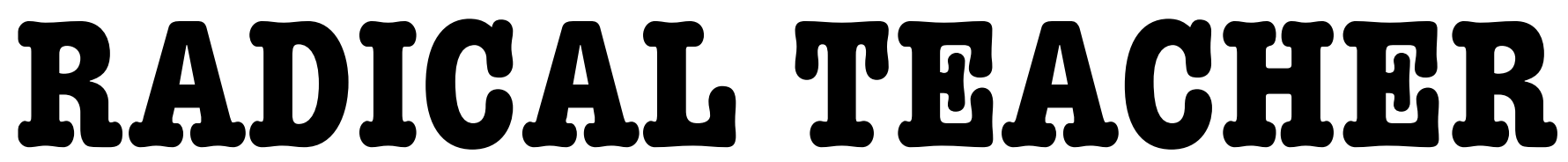

A SOCIALIST, FEMINIST, AND ANTI-RACIST JOURNAL ON THE THEORY AND PRACTICE OF TEACHING

Poems

Fasces Americae and Walt Whitman's House

by Fred Marchant

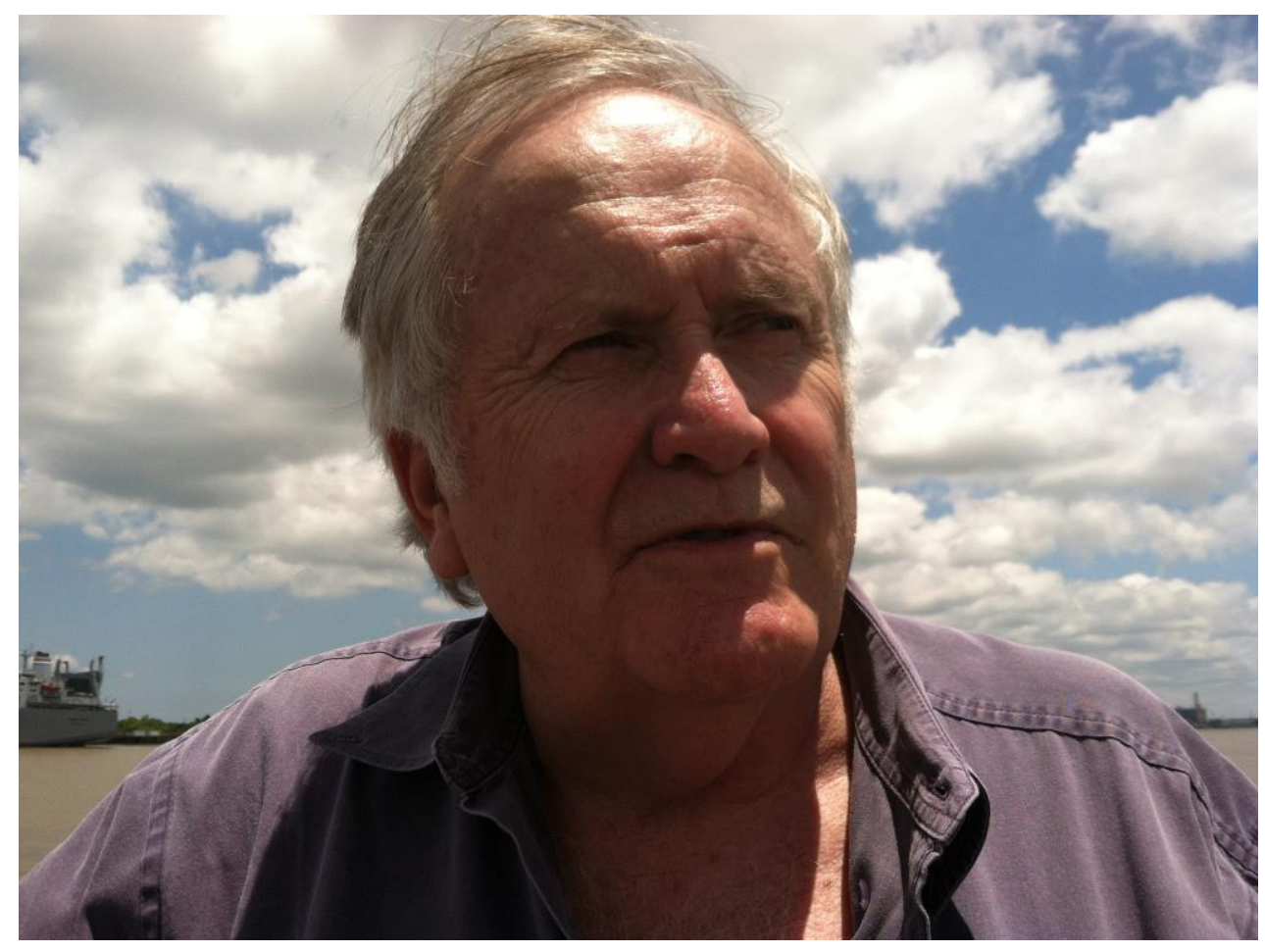

FRED MARCHANT, PHOTO COURTESY OF AUTHOR 


\section{Fasces Americae}

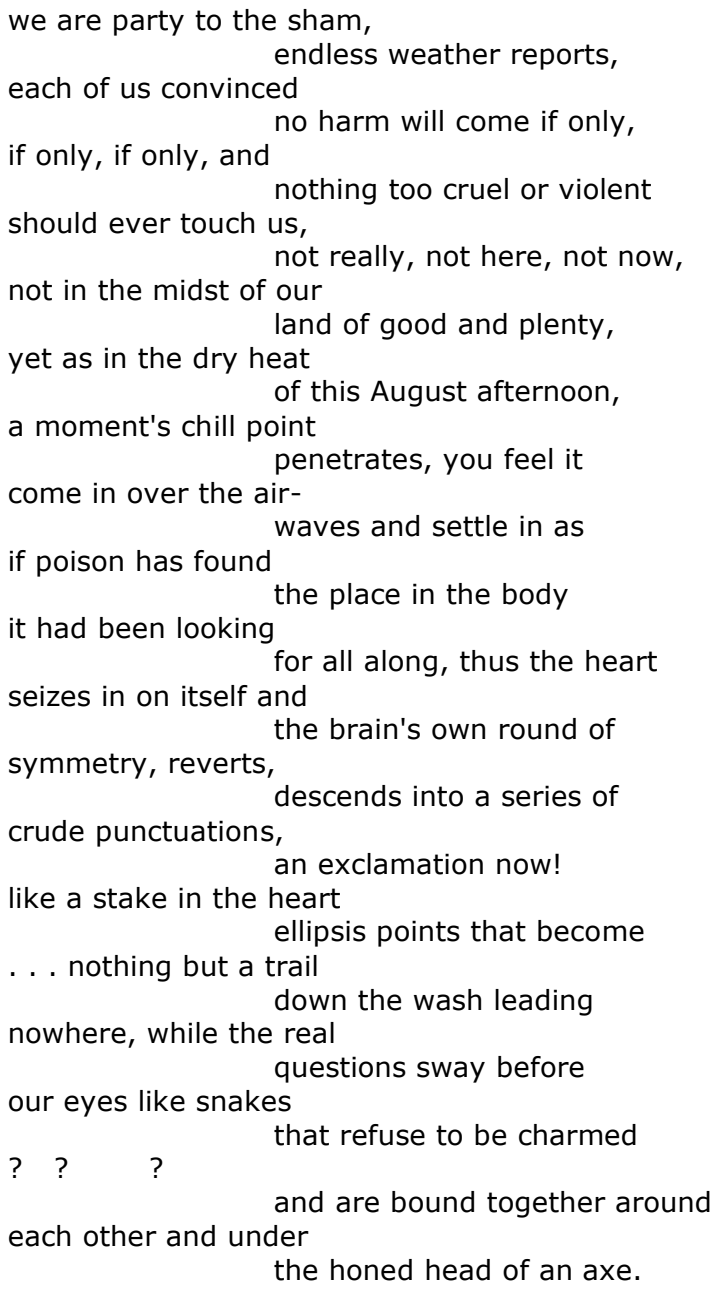




\section{Walt Whitman's House}

\section{Camden}

His last one, two floors, two granite slabs for his doorstep, empty lots and snowy vastness surrounding, rows of row-houses torn down.

Across the street the beige bricks of the jail, a bus-stop, a few metallic window-slots five or six floors up. I think mostly of his kind eyes,

how they would have taken in the jail, the jailers, the inmates, the friends and lovers at the bus-stop waiting for the bus, the snow falling, going home all.

How in their sleep he might visit, touch their lips and try to keep them warm with feelings no one, not even the poets of then or now, know the name of.

Outside his house in the white snow, on the drifts rising like waves frozen, a vast stone ship of state is lit up, its hold filled to the limit, and about to sink. 